\title{
STUDIES ON SOME ECOLOGICAL ASPECTS OF SAND TERMITE, PSAMMOTERMES HYPOSTOMA (DESN.), AT ISMAILIA GOVERNORATE
}

\author{
EL-DOSSOKI, S. A. ${ }^{1}$, S. M. EL-AWADY ${ }^{1}$, Y. EL-SEBAY ${ }^{2}$ \\ AND A. R. EL-BASSIOUNY2
}

1. Fac. of Agric., El-Azhar University, Cairo

2. Plant Protection Research Institute, ARC, Dokki, Giza

(Manuscript received 14 May 2008)

\begin{abstract}
Study of sand termite, P. hypostoma (Desn.), throughout two successive years in 1995 and 1996, clarified that, the termite individuals were abundant during winter and autumn seasons. The workers, first and second nymphs and soldiers were abundant in the winter and reduced during summer season. On the other hand, swarming of winged castes (alates) was occurred during autumn and summer months. The population of workers represented the highest percentages from the total numbers of gallery, followed by soldiers, nymphs and alates. In summer 1995 and 1996, the attraction rate of traps in the tested area (surface activity) was higher during autumn and winter and lower in summer, while the surface activity (food consumption and soil translocated without insects) was higher during summer and autumn, while was lower during winter season throughout 1995 and 1996. Also the highest number of caughted traps was recorded during winter and the lowest one occurred during summer. Food consumption by termites was higher during spring and summer, while it was lower during winter. Soil translocation (construction) showed also the same trend.
\end{abstract}

\section{INTRODUCTION}

The termite one of the social insects distributed all over the world. The sand termites psammotermes hypostoma (Desn.), Rhinotermitidae in Egypt has very economic importance as a subterranean termites which attack any host contained any source cellulose wood, trees, buildings, papers and crops ....etc. This pest causes a tremendous damage to the all buildings and plants contained cellulose material which is located in the desert regions caused a higher destruction and losses in human dwellings. Most of the damage occurs in the villages located on the border between the arid, semi-arid for both the eastern and western desert. In USA alone the assessment of losses caused by termites was evaluated at $\$ 400,000,000$ $500,000,000$ per year, repairs and its control Baker (1972). In Egypt Morsy et al. (1982) estimated the loss due to sand termite, P. hypostoma and harvester termite, Anacanthotermes ochraceus (Burm.) attacks in the New Valley to be 200,000 Egyptian 
pounds. Due to the hidden life behavior of sand termite, psammotermes hypostoma, it is very difficult for ecological studies. Some ecological studies were carried out on sand termite, psammotermes hypostoma, by some researchers i.e., Ali et al. (1982), Morsy et al. (1982), Abdel-Wahab et al. (1983), Rizk et al. (1985), and Salman et al. (1987)

The present study has been carried out throughout 1995 - 1996 at Ismailia Governorate as an ecological study on sand termite, psammotermes hypostoma, which including the following: number of attracted termites., rate of food consumption, rate of soil translocation, seasonal activity, seasonal fluctuation of castes and caste composition.

\section{MATERIALS AND METHODS}

To study the ecology of psammotermes hypostoma (Desn.), field experiments were carried out for two successive years 1995 and 1996 at Ismailia Governorate, 120 $\mathrm{km}$ east of Cairo. Experimental area is cultivated by guava trees. The ground was cleaned-up from any source of cellulose such as weeds and herbs. El-Sebay modified traps (El-Sebay 1991) were used to insect collection for study the ecology of $P$. hypostoma. This trap consists of corrugated-card wrapped in a roll shape, $5-7 \mathrm{~cm}$ in diameter and $12 \mathrm{~cm}$ in length, covered with polyethylene sheath except $2 \mathrm{~cm}$ at the end position fixed with rubber band, Fig. (1a), traps assigned to study three ecological aspects of termites, number of attracted termites, rate of food consumption and rate of soil translocation, such trap was considered suitable for requirements of termites because it contains enough source of moisture and cellulose and also the corrugatedcard board representing site just like tunnels which attracted the different castes to live in as a nest. One hundred and forty traps were prepared at Termite Research Unit, Plant Protection Research Institute, Dokki, Giza. Traps were dried in an electrical oven at $105 \mathrm{C}^{\circ}$ for 24 hours until the weight was stable and sent to the experimental area. At the field, traps were distributed throughout $456 \mathrm{~m} 2$ of infested area and aligned in 20 rows and 7 columns under the ground level with $2 \mathrm{~m}$ intervals. Each trap subtended an area of $4 \mathrm{~m}^{2}$, traps were soaked in water and buried in the ground at 15 $\mathrm{cm}$ depth. Each marked trap occupied the same position throughout two successive years. Fig (2), clarified the general distribution traps in the tested area. Traps were renewed monthly (12 times/year) by another traps. Collected traps were carried back to the laboratory for examined of the following points:

\section{Population density (seasonal abundance and activity)}

Traps were inspected and individuals were separated from the traps by small brush, then the different castes were counted and determined into workers, nymphs, soldiers and alates for each trap. 


\section{The soil translocation (rate of construction)}

The translocated soils (attracted soil) were removed from each infested trap separately, placed in petri-dishes and dried at $105 \mathrm{C}^{\circ}$ for 24 hours Fig (1b), and then the weight of dried soils was recorded for each trap after separating the individuals.

\section{The food consumption (rate of construction)}

After removing insects and soil translocated, traps were placed in an oven at $105 \mathrm{C}^{\circ}$ for 24 hours and re-weight to determine the loss of weight due to termites consumption Fig (1c). Data were recorded for each trap.
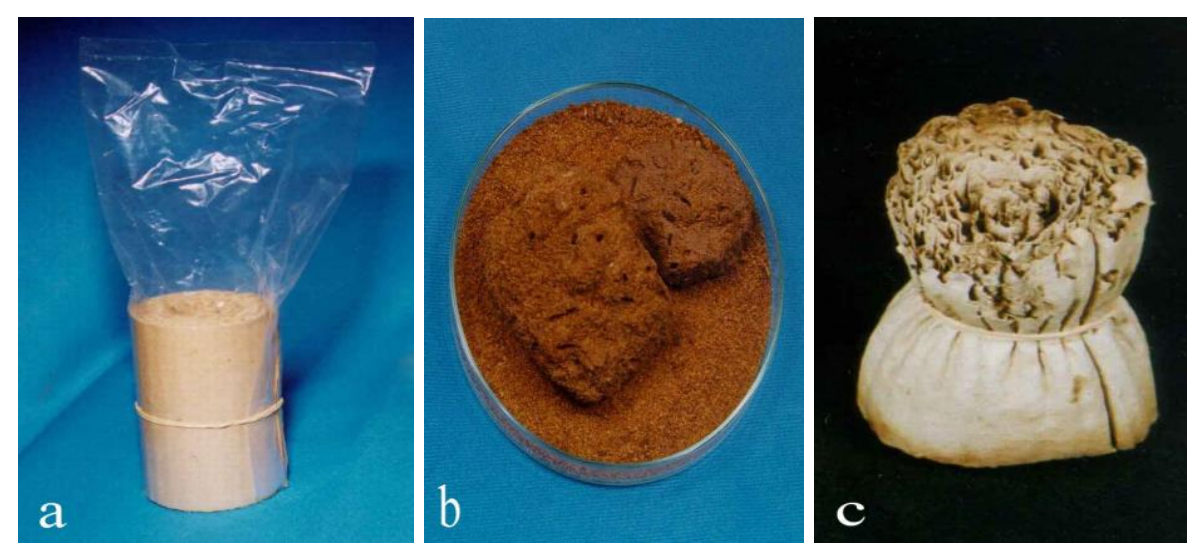

Fig. 1. Illustration of (a) El-Sebay modified trap, (b) soil translocated, (c) infested trap

\begin{tabular}{|c|c|c|c|c|c|c|c|}
\hline 1 & $\begin{array}{r}* \\
21 \\
\end{array}$ & 41 & 61 & $\begin{array}{r}* \\
81 \\
\end{array}$ & 101 & 121 & * \\
\hline 2 & 22 & 42 & 62 & 82 & 102 & 122 & \\
\hline 3 & 23 & 43 & 63 & 83 & 103 & 123 & \\
\hline 4 & 24 & 44 & 64 & 84 & 104 & 124 & \\
\hline 5 & $\begin{array}{r}* \\
25\end{array}$ & 45 & 65 & $\begin{array}{r}* \\
85\end{array}$ & 105 & 125 & $*$ \\
\hline $\begin{array}{l}6 \\
7 \\
\end{array}$ & $\begin{array}{l}26 \\
27 \\
\end{array}$ & $\begin{array}{l}46 \\
47 \\
\end{array}$ & $\begin{array}{l}66 \\
67 \\
\end{array}$ & $\begin{array}{l}86 \\
87 \\
\end{array}$ & $\begin{array}{l}106 \\
107 \\
\end{array}$ & $\begin{array}{l}126 \\
127\end{array}$ & \\
\hline 8 & 28 & 48 & 68 & $\begin{array}{l}* \\
88\end{array}$ & 108 & 128 & $*$ \\
\hline 9 & 29 & 49 & 69 & 89 & 109 & 129 & \\
\hline 10 & 30 & 50 & 70 & 90 & 110 & 130 & \\
\hline 11 & 31 & 51 & 71 & 91 & 111 & 131 & $*$ \\
\hline 12 & 32 & 52 & 72 & 92 & 112 & 132 & \\
\hline 13 & 33 & 53 & 73 & 93 & 113 & 133 & \\
\hline 14 & $\begin{array}{l}* \\
34\end{array}$ & 54 & 74 & $\begin{array}{l}* \\
94\end{array}$ & 114 & 134 & $*$ \\
\hline 15 & 35 & 55 & 75 & 95 & 115 & 135 & \\
\hline 16 & 36 & 56 & 76 & 96 & 116 & 136 & \\
\hline 17 & 37 & 57 & 77 & 97 & 117 & 137 & $*$ \\
\hline 18 & 38 & 58 & 78 & 98 & 118 & 138 & \\
\hline 19 & 39 & 59 & 79 & 99 & 119 & 139 & \\
\hline 20 & * 40 & 60 & 80 & $\begin{array}{l}* \\
100\end{array}$ & 120 & 140 & $*$ \\
\hline
\end{tabular}

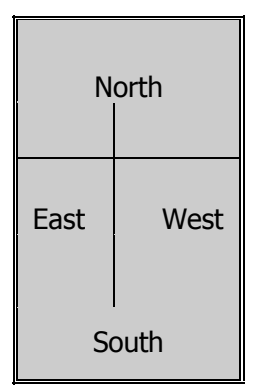

* Guava trees cultivated in the area

Total area $=456 \mathrm{~m}^{2}$ 
Fig. 2. Illustration of general distribution of traps in the tested area.

\section{RESULTS AND DISCUSSIONS}

\section{1- Number of attracted termites}

Data in Tables (1 and 2 ) show that the largest number of attracted termites (16818, represented 31.3\%) was found during December 1995 followed by November (12536, represented 23.3\%). While the least number (31) was found during June. During 1996, the largest number of attracted termites was found in winter season (in January was 11743 and in December was 4744) with percent 37.1 and $14.9 \%$, respectively, while the lowest number (51) occurred during June.

This result is in agreement with that of El-Sebay (1993b) who stated that, the minimum number of foragers ( $A$. ochrocieus) occurred during January, while the maximum one was during February. Similar results were obtained by Ahmed (1997), who mentioned that, the highest number of $A$. ochraceus (Harvester termite) was occurred during January and increased gradually until April. But the results are in disagreement with those of Said (1979), Ali et al (1982) and Salman et al (1987) they reported that the maximum number of (Sand termite) P. hypostoma and (Harvester termite) $A$. ochraceus were occurred during summer season while the lowest number occurred during winter season.

\section{2- Food consumption}

At the experimental area $\left(465 \mathrm{~m}^{2}\right)$ and data presented in Table (1 and 2), estimated loss in traps weight, resulting from termite consumption was $(6.8 \mathrm{~kg})$ during 1995 and $(6.7 \mathrm{~kg})$ during 1996. The largest quantity of consumed food was found during July 1995 (898.2 gm) and August 1996 (923.4 gm). While the lowest one (22.2 gm) was found in January 1995 and of March 1996 was (284.9 gm).

These results coincide with those of Abdel-Wabab et al. (1983) who mentioned that the food consumption was at its minimum level during December and reached its maximum level at August of $P$. hypostoma. El-Sebay (1993b) found that, the weight of food consumption ranged from 535 to $1906 \mathrm{gm} /$ colony/year. However the results are in disagreement with those of Ahmed (1997) who stated that, the trap consumption of A. ochraceus (Burm.) reached its minimum level $1.0 \%$ during July and August and $86.7 \%$ during December, while its maximum level $13.3 \%$ during November and $30.0 \%$ during January. He estimated weight of food consumption reached $36.9 \mathrm{gm} / \mathrm{m}^{2}$ or $154.98 \mathrm{~kg} /$ feddan and $33.8 \mathrm{gm} / \mathrm{m}^{2}$ or $142.06 \mathrm{~kg} /$ feddan in 1994 and 1995, respectively, it my be due to differentiation between localities and species.

\section{3- Construction activity}


Data in Tables (1 and 2) show that, the highest weight translocated soil (5086.23 gm) was found during October 1995 (21.9\%), during 1996, the highest weight was $(5067.3 \mathrm{gm})$ in September representing $19.7 \%$. The least number of translocated soil occurred in January 1995 (31.3 gm and represented 0.13\%) and $(137.8 \mathrm{gm})$ in January 1996 represented $0.53 \%$. Generally data illustrated that the food consumption was increased during July-October, and decreased during December-April, translocated soil (construction rate) showed the same trend as in food consumption (increase in summer and decrease in winter and spring).

Table 1. Ecological aspects of psammotermes hypostoma (Desn.) as indicated by traps at Ismailia Governorate during 1995.

\begin{tabular}{|c|c|c|c|c|c|c|}
\hline \multirow[b]{2}{*}{ Month } & \multicolumn{6}{|c|}{ Ecological aspects } \\
\hline & $\begin{array}{c}\text { No. of } \\
\text { attracted } \\
\text { insects }\end{array}$ & $\%$ & $\begin{array}{c}\text { Food } \\
\text { consumption in } \\
\mathrm{gm} \\
\end{array}$ & $\%$ & $\begin{array}{c}\text { Translocated soil } \\
\text { in gm }\end{array}$ & $\%$ \\
\hline Jan. & 3176 & 5.91 & 22.2 & 0.32 & 31.3 & 0.13 \\
\hline Feb. & 3310 & 6.16 & 134 & 1.96 & 448.57 & 1.93 \\
\hline Mar. & 3606 & 6.71 & 898.19 & 13.1 & 1303.42 & 5.61 \\
\hline Apr. & 2860 & 5.32 & 439.34 & 6.44 & 1280.41 & 5.51 \\
\hline May & 806 & 1.50 & 370.74 & 5.43 & 3010.15 & 12.97 \\
\hline June & 31 & 0.05 & 596.58 & 8.75 & 2057 & 8.86 \\
\hline July & 999 & 1.80 & 898.3 & 13.1 & 2887.78 & 12.44 \\
\hline Aug. & 1112 & 3.07 & 777.26 & 11.4 & 2109.88 & 9.09 \\
\hline Sep. & 2063 & 3.84 & 844.84 & 12.3 & 3817.69 & 16.45 \\
\hline Oct. & 6377 & 11.8 & 732.11 & 10.7 & 5086.23 & 21.92 \\
\hline Nov. & 12536 & 23.3 & 685.78 & 10.05 & 808.08 & 3.48 \\
\hline Dec. & 16818 & 31.3 & 417.63 & 6.12 & 257.96 & 1.54 \\
\hline Total & 53694 & 100 & 6816.97 & 100 & 23199.07 & 100 \\
\hline
\end{tabular}

Table 2. Ecological aspects of psammotermes hypostoma (Desn.) as indicated by traps at Ismailia Governorate during 1996.

\begin{tabular}{|c|c|c|c|c|c|c|}
\hline \multirow[b]{2}{*}{ Month } & \multicolumn{6}{|c|}{ Ecological aspects } \\
\hline & $\begin{array}{l}\text { No. of } \\
\text { attracted } \\
\text { insects }\end{array}$ & $\%$ & $\begin{array}{c}\text { Food } \\
\text { consumption in } \\
\mathrm{gm}\end{array}$ & $\%$ & $\begin{array}{c}\text { Translocated soil } \\
\text { in } \mathrm{gm}\end{array}$ & $\%$ \\
\hline Jan. & 11743 & 37.09 & 358.36 & 5.36 & 137.81 & 0.53 \\
\hline Feb. & 1769 & 5.58 & 384.9 & 5.76 & 202.78 & 0.8 \\
\hline Mar. & 2780 & 8.78 & 284.89 & 4.26 & 313.01 & 1.2 \\
\hline Apr. & 2860 & 9.03 & 439.34 & 6.57 & 1280.38 & 4.91 \\
\hline May & 1024 & 3.23 & 486.54 & 7.28 & 2297.38 & 8.92 \\
\hline June & 51 & 0.16 & 806.88 & 12.07 & 2639.85 & 10.3 \\
\hline July & 940 & 2.96 & 747.64 & 11.19 & 2108.7 & 8.2 \\
\hline Aug. & 744 & 2.35 & 923.44 & 13.82 & 2044.52 & 7.94 \\
\hline Sep. & 1078 & 3.4 & 479.23 & 7.17 & 5067.3 & 19.7 \\
\hline Oct. & 2014 & 6.36 & 785.25 & 11.75 & 4794.99 & 18.6 \\
\hline Nov. & 1909 & 6.03 & 572.78 & 8.57 & 4126.52 & 16.03 \\
\hline Dec. & 4744 & 14.98 & 411.05 & 6.15 & 724.03 & 2.81 \\
\hline Total & 31656 & 100 & 6680.30 & 100 & 25737.27 & 100 \\
\hline
\end{tabular}


On the other hand, foraging activity increased during winter and spring and failed during summer season. Accordingly, these results proved that, foraging activity was increased during winter and stopped during June due to increasing of surface temperature of soil, and termite increased its food consumption under the ground activity (subsurface activity). By increasing of food consumption and subsurface activity, rate of construction was increased with the consumed traps. El-Sebay (1993a) estimated the rate of soil translocated of $A$. ochraceus was $58 \mathrm{gm} / \mathrm{m}^{2}$ or 243 $\mathrm{kg} /$ feddan or ranged from 1878 to $6726 \mathrm{gm} /$ colony/year. This result is in line with that of Said (1979) who stated that, the quantity of translocated soil reached its maximum during July-August and September, while its minimum was obtained during the winter and spring. But, this result is in disagreement with that of Ahmed (1997) at Fayoum, who found that translocated soil of $A$. ochraceus reached its maximum during January, February and March, while its minimum was reached during November.

\section{4 -Seasonal activity}

Data presented in Tables ( 3 and 4) show that the maximum number of foraged workers was (16167) during December 1995, which were 10794 during January 1996 (represented 32.5 and 36.5, respectively). The minimum number was at June in both years 1995 and 1996 (17 and 40, respectively). This result is in agreement with that of Rizk et al. (1985) who stated that workers of psammotermes hypostoma were found all over the year except from May to August. He mentioned that, the workers population curve has two peaks during February/March and August/September, and two bottoms during May/July and November/December.

The largest number of first and second nymphal instars occurred during February, March and September 1995), while was during September and October 1996 , but the lowest number occurred during June in both years. These results are in line with those of Rizk et al. (1985) who found that the nymphs occurred during and shortly after swarming and he mentioned that the larval abundance occurred during May to August.

On the other hand, the largest number of soldiers occurred (568, 533 and 428) during October, November and December in 1995, while it occurred during January, March and December in 1996 (411, 155 and 148 soldiers). The least number occurred during June 1995 and 1996. These results are in agreement with the findings of Rizk et al. (1985) who stated that soldiers positively correlated with the total number of the various forms.

Alates was found from September to December 1995 while during January to March and from October to December in 1996. The results are in line with those of 
Rizk et al. (1985) who mentioned that, the flight activity at western desert in Egypt was in April and in August.

Results in Tables ( 3 and 4 ) show that the most seasonal activity of workers was found during winter season and extended to spring season. Such surface activity was done by the workers in order to collect food and store it inside nest chamber for consumption during the summer season (where termite has no surface foraging), because of hot surface of soil. The occurrence of small nymphs during February and March revealed that, most of eggs were laid during winter season and no eggs were achieved during summer season. Also data in tables indicate that the largest number of soldiers was found during winter to protect the surface activity of the workers during their activity in food storage inside the colony. On the other hand, under Egyptian conditions swarming of alates was found during October-January and February-March. The obtained results are in agreement with those of Rizk et al. (1985), but in disagreement with those of Ali et al. (1982), who mentioned that the termite reached its maximum activity during spring and late-summer months, whereas the minimum was during winter and autumn months. The infestation level of psammotermes hypostoma was higher in Sohag Governorate than in the New Valley.

\section{5 - Seasonal fluctuation of castes}

As shown in Tables (3 and 4) smoothed numbers of workers were found highly during December 1995, and during January 1996. The lowest smoothed number was found during May and June in both tested years. The average number of workers reached its maximum (16167) during December 1995, this number dropped drastically to only 2988 workers during the next month (January). Minimum workers number was recorded during May, then increased gradually during the summer months and reached its maximum during December of the same year. The low levels of $P$. hypostoma population during summer time (June) could be due to occurring of high temperature at the soil surface (around $40 \mathrm{C}^{\circ}$ ).

Generally, workers fluctuation increased from January and reach its peak during March 1995, then decreased to the least number during June 1995. Hence increased again to reach its peak around December 1995. In 1996, workers reached its peak around January and decreased around May and June in both years. Maximum smoothed numbers of soldiers were found during October 1995 and January 1996. While the least number was found during May and June in both 1995 and 1996. Nymphal population fluctuated throughout the year. While alates showed their peaks during December and January in 1995 and 1996. 


\section{6 - Caste composition}

Data shown in Table (5), revealed that the maximum number of workers was occurred during winter season followed by autumn season (21850 and 19513 individuals), in 1995 and 17017 in winter followed by spring season (6332 individuals) in 1996. While the lowest numbers was found during summer season for both tested years (1955 and 1579, respectively). Nymphs were found all over the year, its peak during autumn and winter in 1995, represented 1283 and 803 individuals, respectively. During 1996, the nymphs' peak was registered during winter, counted (652 individuals), while the lowest number was occurred during summer time in both years. Soldiers were abundant during winter and spring during 1995, while the lowest soldiers' numbers were estimated during summer. In seasons of 1996, soldiers recorded a lowest numbers, and reached its peak during autumn.

Table 3. Annual activity (surface activity) of caste composition of Psammotermas hypostoma (Desn.) as indicated by attracted termites to the traps at Ismailia Governorate during 1995.

\begin{tabular}{|c|c|c|c|c|c|c|c|c|c|}
\hline \multirow{2}{*}{ Month } & \multicolumn{7}{|c|}{ Caste activity } & \multirow{2}{*}{ Average } \\
\cline { 2 - 9 } & Workers & \multicolumn{2}{|c|}{ Nymphs } & \multicolumn{2}{c|}{ Soldiers } & \multicolumn{2}{|c|}{ Alates } & total \\
\cline { 2 - 10 } & No. & $\%$ & No. & $\%$ & No. & $\%$ & No. & $\%$ & population \\
\hline \multirow{2}{*}{ Jan. } & 2988 & 6.02 & 0 & 0.00 & 188 & 7.23 & 0 & 0.00 & 3176 \\
\hline Feb. & 2695 & 5.43 & 428 & 35.28 & 187 & 7.19 & 0 & 0.00 & 3310 \\
\hline Mar. & 2863 & 5.77 & 532 & 43.86 & 211 & 8.10 & 0 & 0.00 & 3606 \\
\hline Apr. & 2747 & 5.54 & 7 & 0.58 & 106 & 4.07 & 0 & 0.00 & 2860 \\
\hline May & 698 & 1.40 & 29 & 2.39 & 79 & 3.03 & 0 & 0.00 & 806 \\
\hline June & 17 & 0.03 & 0 & 0.00 & 14 & 0.53 & 0 & 0.00 & 31 \\
\hline July & 938 & 1.89 & 34 & 2.80 & 27 & 1.03 & 0 & 0.00 & 999 \\
\hline Aug. & 1000 & 20.2 & 33 & 2.73 & 79 & 3.03 & 0 & 0.00 & 1112 \\
\hline Sep. & 1740 & 3.51 & 140 & 11.54 & 182 & 6.99 & 1 & 0.39 & 2063 \\
\hline Oct. & 5780 & 11.65 & 9 & 0.74 & 568 & 21.82 & 20 & 7.90 & 6377 \\
\hline Nov. & 11993 & 24.17 & 1 & 0.08 & 533 & 20.48 & 9 & 3.55 & 12536 \\
\hline Dec. & 16167 & 32.58 & 0 & 0.00 & 428 & 16.44 & 223 & 88.14 & 16818 \\
\hline Total & 49626 & & 1213 & & 2602 & & 253 & & 53694 \\
\hline
\end{tabular}


Table 4. Annual activity (surface activity) of caste composition of Psammotermas hypostoma (Desn.) as indicated by attracted termites to the traps at Ismailia Governorate during 1996.

\begin{tabular}{|c|c|c|c|c|c|c|c|c|c|}
\hline \multirow{2}{*}{ Month } & \multicolumn{7}{|c|}{ Caste activity } & \multirow{2}{*}{ Average total } \\
\cline { 2 - 10 } & \multicolumn{2}{|c}{ Workers } & \multicolumn{2}{|c|}{ Nymphs } & \multicolumn{2}{c|}{ Soldier } & \multicolumn{2}{c|}{ Alates } \\
\cline { 2 - 10 } & No. & $\%$ & No. & $\%$ & No. & $\%$ & No. & $\%$ & \\
\hline \multirow{2}{*}{ Jan. } & 10794 & 36.56 & 2 & 0.91 & 411 & 31.90 & 536 & 90.38 & 11743 \\
\hline Feb. & 1664 & 5.63 & 4 & 1.83 & 93 & 7.22 & 8 & 1.34 & 1769 \\
\hline Mar. & 2584 & 8.75 & 7 & 3.12 & 155 & 12.03 & 34 & 5.73 & 2780 \\
\hline Apr. & 2747 & 9.30 & 7 & 3.12 & 106 & 8.22 & 0 & 0.00 & 2860 \\
\hline May & 1001 & 3.39 & 0 & 0.00 & 23 & 1.78 & 0 & 0.00 & 1024 \\
\hline June & 40 & 0.13 & 0 & 0.00 & 1 & 0.07 & 10 & 1.68 & 51 \\
\hline July & 896 & 3.03 & 21 & 9.63 & 23 & 1.78 & 0 & 0.00 & 940 \\
\hline Aug. & 643 & 2.17 & 4 & 1.83 & 97 & 7.53 & 0 & 0.00 & 744 \\
\hline Sep. & 961 & 3.25 & 85 & 38.99 & 32 & 2.48 & 0 & 0.00 & 1078 \\
\hline Oct. & 1817 & 6.15 & 77 & 35.32 & 119 & 9.23 & 1 & 0.16 & 2014 \\
\hline Nov. & 1815 & 6.14 & 11 & 5.04 & 80 & 6.21 & 3 & 0.50 & 1909 \\
\hline Dec. & 4559 & 15.44 & 0 & 0.00 & 148 & 11.49 & 1 & 0.16 & 4708 \\
\hline Total & 29521 & & 218 & & 1288 & & 593 & & 31656 \\
\hline
\end{tabular}

Alates were found during winter and autumn in both years and mainly during winter (223 in 1995 and 536 in 1996).

Generally according to tables ( 3 and 4 ) the percentages of castes of Psammotermas hypostoma represented 92.4, 2.2, 4.8 and $0.47 \%$ for workers, nymphs, soldiers and alates (in 1995). While their percentages in 1996 were 93.2, $0.68,4.06$ and $1.87 \%$ for the same castes, respectively.

El-Sebay (1993b) found that the caste composition of $A$. ochraceus (Burm.) were $66.0,31.0$ and 3.0 for workers, nymphs and soldiers, respectively. The highest number of workers occurred during December, while the least number occurred during June. Nymphs were highest during March, while the lowest were occurred during June and January. Soldiers were highest during October and the lowest were occurred during June. The highest number of alates occurred during December, while were nearly absent the rest of months. Ahmed (1997) found that the average percentages castes of $A$. ochraceus were $66.5,32.4,0.7$ and 0.4 for workers, nymphs, soldiers and alates in 1994, while they 77.1, 21.7, 0.2 and 0.9 for the same castes in 1995. Lafage et al. 1973 studied the caste composition of Heterotermes aureus. He found that soldiers represented $4 \%$ of the total population foraging of Gnathamitermes preplexus has been reported to contain mainly workers and only about $0.4 \%$ soldiers. 
According to table (5), the general conclusion revealed that, seasonal fluctuation of castes (workers, nymphs, soldiers and alates), were highly abundant during winter, autumn and spring seasons, while, the castes were lower abundant in summer season in both years.

Table 5. Caste composition of psammotermes hypostoma (Desn.) during 1995 and 1996, at Ismailia Governorate, as indicated by attracted termites.

\begin{tabular}{|c|c|c|c|c|c|}
\hline \multirow{3}{*}{ Year } & \multicolumn{5}{|c|}{ Caste activity } \\
\cline { 2 - 6 } & Season & Workers & Nymphs & Soldiers & Alates \\
\hline \multirow{3}{*}{ 음 } & Winter & 21850 & 803 & 458 & 223 \\
\cline { 2 - 6 } & Spring & 6308 & 396 & 568 & 0 \\
\cline { 2 - 6 } & Summer & 1955 & 120 & 97 & 0 \\
\cline { 2 - 6 } & Autumn & 19513 & 1283 & 150 & 30 \\
\hline \multirow{3}{*}{ ᄋั } & Winter & 17017 & 652 & 6 & 545 \\
\cline { 2 - 6 } & Spring & 6332 & 284 & 14 & 34 \\
\cline { 2 - 6 } & Summer & 1579 & 121 & 45 & 10 \\
\cline { 2 - 6 } & Autumn & 4593 & 231 & 173 & 4 \\
\hline
\end{tabular}

\section{REFERENCES}

1. Abdel-Wahab, A. M., M. R. Rizk, M. H. Hussin, T. K. Abd El-Raof and M. S. ElTaib. 1983. Surface activity of sand termites Psammotemes hypostoma Desneux in Aswan. Assuit J. Agric. Sec., 14(3): 99-108.

2. Ahmed, H. M. 1997. Ecological control studies on subterranean termite, Anacanthotermes ochraceus (Burm), at Fayoum Gov. M.Sc. thesis, Cairo University, Fayoum.

3. Ali, A. M., M. F. Abou-Ghadir and N. A. Abdel-Hafez. 1982. Surface activity of termite in the New Valley. Assiut J. Agric. Sci., 13 (3): 73-78.

4. Baker, W. L. 1972. Estern Forest Insects. U.S.D.A. Forest Serv. Miscell. Publ. No.1175.

5. El-Sebay, Y. 1991. A modified trap for El-Sebay subterranean termite. Fourth Arab Cong. of Plant Protection, Cairo, 1-5 Dec. 1991.

6. El-Sebay, Y. 1993a. A trail to delineate A. ochraceus (Burm.) foraging territories in Ismailia Governorate, Egypt. J. Agric. Recs., 73 (1): 71-81.

7. El-Sebay, Y. 1993b. Ecological studies on the harvester subterranean termites, $A$. ochraceus (Burm.) in Egypt. Assuit J. Agric. Sci., 24 (4): 35-47.

8. Lafage, J. P., W. L. Nutting and M. I. Harverty. 1973. Desert subterranean termite: A method for studying foraging behavior. Environ. Entomol. 2: 954-956.

9. Morsy, M. M., M. M. Rizk and F. M. Khalil. 1982. Effect of Thermo Rhythm on termite food consumption. Assiut J. Agric. Sci., 13 (3): 43-50. 
10. Rizk, M. M. A., A. K. El-Sayed, A. Maher Ali and S. A. Eraky. 1985. Flight activity and annual caste fluctuation of sand termite Psammotermes hypostoma Desn. Western Desert, Egypt. Assiut J. Agric. Sci., 16 (2): 137-148.

11. Said, W. A. 1979. Ecological and toxicological studies on Fam. Hodotermitidae, M. Sc. Thesis, Fac. of Agric., Ain-Shams Univ., Egypt.

12. Salman, A. G. A., M. A. A. Morsy and A. A. Sayed. 1987. Foraging activity of the sand termite, Psammotermes hypostoma Desn. In the New Valley, Egypt. Assuit J. Agric. Sci., 18 (4): 51-57. 


\section{دراسة بعض المظاهر الإيكولوجية للنمل الأبيض (نمل الرمال) "ساموترمس هيبوستوما" فحى محافظة الإسماعيلية}

سامى عبد الحميا الاسوقى' ، شلبى محمد العوضى' ، يسرى محمد عبد المنعم السباعى' ،

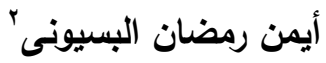

$$
\begin{aligned}
& \text { ا ـ قسم وقاية النبات - كلبة الزراعة - جامعة الأزهر - القاهرة }
\end{aligned}
$$

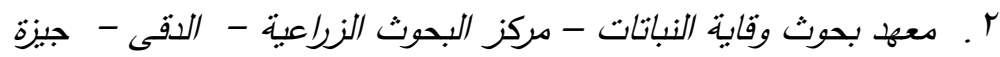

1- الأعداد الحشرية Number of attracted termites : وجد أن أعلي نسبة لأعداد الحشرات المنجذبة عن طريق المصائد كانت في اواخر الخريف وفي فصل الثتاء (نوفمبر ، ديسمبر) بينما كانت النسبة

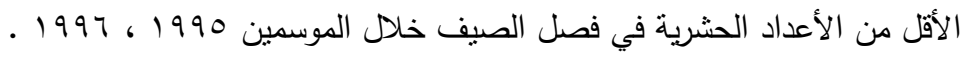
r- الاستهلاك الغذائي Food consumption : لقد أعطى الوزن المفقود من المصايد أعلي نسبة خلال شهر يوليو 1990 وأغسطس 1997. ولكن أعطي النسبة الأقل خلال شهر يناير ، مارس 1990 ، 1909

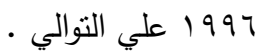
r- النشاط البنائي Construction activity : أظهرت النتائج أن أعلي كمية بناء قد سجلت خلال أكتوبر

1990 ، سبتمبر 1997 علي التوالي . وأقل كمية بناء قد سجلت خلال شهر يناير في الموسمين .

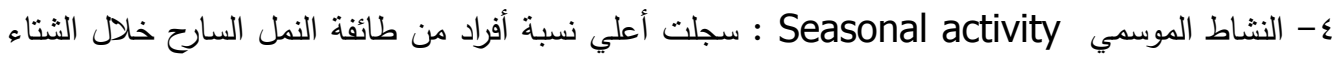
علي العكس سجلت أقل نسبة خلال فصل الصبف في كلا الموسمين 1990 ، 1997 19 ـ وكانت الحوريات في العمر الأول والثاني مرتفعة خلال فصل الثتاء 1990 ووجدت خلال فصل الصيف 1997 ولكن سجلت أقل أعداد من الحوريات خلال شهر يونيو في الموسمين ـ من ناحية أخري كانت أعداد الجنود

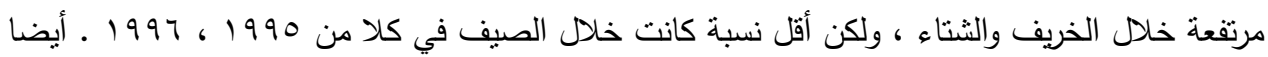

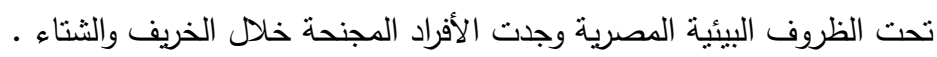
ه- تركيب المستعمرة Caste composition : وجدت غالبية أعداد الثغالات عموما خلال موسم الثتاء

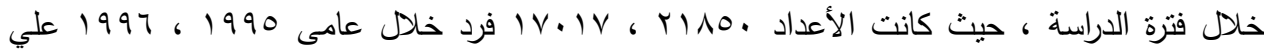
التوالي ، كما تم تسجيل أعداد قليلة خلال الصيف ـ كذللك كانت أعداد الجنود مرتفعة خلال الثتاء ومنخفضة خلال الصبف ، ووصلت أعداد الأفراد المجنحة ذروتها خلال فصل الثتاء وأدنى مسنوى لها كالهيل

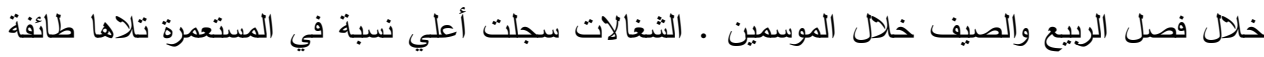

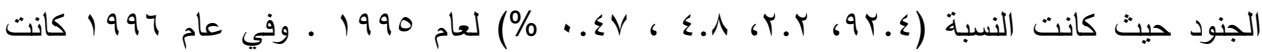

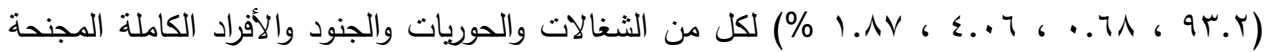

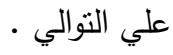

צ- التنبذب الموسمي للمستعمرة Seasonal caste composition : نزايدت أعداد الثغالات ابتداء من

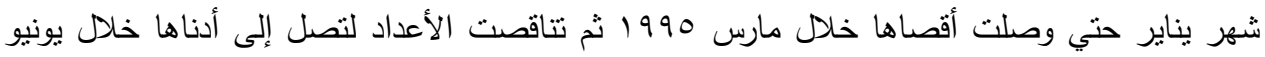
لتزداد مرة أخري لتصل أقصاها خلال ديسمبر 1990 ـ وفي 1997 تزايدت أعداد الحشرات لتصل ذروتها في يناير ثم تناقصت تدريجيا لتصل لحدها الأدنى في الموسمين ـ وتزايدت طائفة الجنود لتصل أقصاها

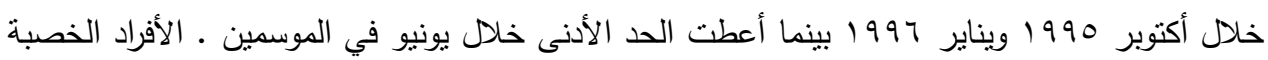
المجنحة سجلت قمنين خلال ديسمبر ويناير في الموسمين علي النوالي . 